\title{
Influence of Milk, Corn Starch, and Baking Conditions on the Starch Digestibility, Gelatinization, and Fracture Stress of Biscuits
}

\author{
Paula A. Conforti, ${ }^{1,2}$ Diego K. Yamul, ${ }^{2}$ and Cecilia E. Lupano ${ }^{2,3}$
}

ABSTRACT

Cereal Chem. 89(4):205-210 than biscuits baked at high temperature. The degree of starch gelatinization during baking was higher when dough was baked at $170^{\circ} \mathrm{C}$, compared with dough baked at $120^{\circ} \mathrm{C}$. The decrease in gelatinization coincides with the decrease in the height and surface of peaks at 15 and $23^{\circ}$ in the X-ray diffraction patterns. Milk and corn starch did not affect the starch digestibility of biscuits, but biscuits baked at $170^{\circ} \mathrm{C}$ presented lower fracture stress and higher starch digestibility than biscuits baked at $120^{\circ} \mathrm{C}$.
Biscuits have become a traditional and significant food in many countries because of their taste, long shelf life, and relatively low cost. They are usually thought of as a source of pleasure and energy. The great majority of biscuits are rich in sugar and fat, and they have sometimes been regarded as unhealthy foods (Manley 2000c). However, ingredients and proportions can be varied to obtain more healthy products, for example, through the incorporation of fiber (Artz et al 1990; Vitali et al 2009) or resistant starch (Aparicio-Saguilán et al 2007; Laguna et al 2011) or by replacing sucrose with fiber (Pareyt et al 2011). The addition of milk enhances the nutritional value of these products; also, the protein and lactose contents of milk contribute strongly to the Maillard reaction, which gives attractive golden brown surface coloration to biscuits during baking (Manley 2000b). Corn starch may be used to dilute the biscuit flour; it helps to make the dough less tough and easier to sheet, and it makes the texture of biscuits more delicate (Manley 2000a).

Starch is the largest source of carbohydrates in human food. The physical state of the starch has a major impact on the digestibility; therefore, the processing techniques have an important effect on its nutritive value (Sagum and Arcot 2000; Singh et al 2010). Starch digestibility in the human small intestine can vary from a rapid digestion, in particular for the products of starch hydrolysis, to indigestibility, which is the case in resistant starch. The starch fraction that is resistant to enzyme digestion, or resistant starch, is divided into four types: physically inaccessible starch, entrapped in a cellular matrix (type 1); native, ungelatinized starch (type 2); retrograded starch (type 3) (Sáyago-Ayerdi et al 2005); and chemically modified starch (type 4). Resistant starch is considered by many authors as part of dietary fiber (McCleary and Monaghan 2002). The interest in foods with fiber contents has increased in recent decades, and the importance of this food constituent has led to the development of a large market for fiber source ingredients in products such as bread, snacks, muffins, and cookies (Laguna et al 2011).

When starchy foods are heated in excess water, the crystalline structure of starch is disrupted, followed by swelling and solubilization. This process is called gelatinization. It is well known that

\footnotetext{
${ }^{1}$ Facultad de Ciencias Agrarias y Forestales, UNLP, 60 y 116, 1900 - La Plata, Argentina.

${ }^{2}$ Centro de Investigación y Desarrollo en Criotecnología de Alimentos (CIDCA), Facultad de Ciencias Exactas, UNLP-CCT La Plata CONICET, 47 y 116, 1900 La Plata, Argentina.

${ }^{3}$ Corresponding author. Phone: +54221425 4853. Fax: +54 221425 4853. E-mail: cel@quimica.unlp.edu.ar
}

http://dx.doi.org/10.1094/CCHEM-11-11-0138

(c) 2012 AACC International, Inc. gelatinization is strongly affected by water content (Biliaderis et al 1980); therefore, the water activity or the availability of water during baking is an important factor that determines the extent of starch digestibility through enzymatic hydrolysis (Sagum and Arcot 2000; Singh et al 2010). The other constituents of the food matrix, such as proteins and lipids, play a significant role during processing and also affect the digestibility of the starch (Singh et al 2010). Thus, the gelatinization and digestibility of starch must be studied in different biscuit recipes.

Leon et al (1998) analyzed starch behavior during one baking condition of biscuits prepared with triticale flour, and Laguna et al (2011) studied the effect of replacing part of the wheat flour with a resistant starch-rich ingredient in short-dough biscuits. However, biscuits could contain resistant starch depending on the baking conditions. The aim of the present work was to analyze if the baking conditions affected the degree of gelatinization and digestibility of the starch and the texture of nontraditional semisweet biscuits. To achieve this objective, four formulations with the ratios of sucrose and lipid to flour corresponding to semisweet biscuits but with higher moisture contents (Manley 2000d) were baked under two different conditions of time and temperature. Some of these formulations contained milk, to enhance the nutritional value of these products, or corn starch, which was used to modify the texture of biscuits.

\section{MATERIALS AND METHODS}

\section{Materials}

The ingredients included wheat flour (ash content less than $0.650,10.1 \%$ protein, $14.7 \%$ moisture, a gift of S.A. Miguel Campodónico Ltda., La Plata, Pcia. Buenos Aires, Argentina), corn starch (Maizena, Unilever de Argentina S.A., Buenos Aires), corn oil (Cocinero, Molinos Río de La Plata S.A., Buenos Aires, Argentina), sucrose (Ledesma, Jujuy, Argentina), baking powder (Royal, Kraft Foods, Buenos Aires, Argentina), and skim milk powder (Purísima, S.A. La Sibila, Nogoyá, Entre Ríos, Argentina).

The amylase preparation (porcine pancreatic $\alpha$-amylase type VI-B, A3176, Sigma Chemical Co., St. Louis, MO) contained approximately 19.6 units/mg of solid. One unit is defined by the manufacturer as releasing $1 \mathrm{mg}$ of maltose per $3 \mathrm{~min}$ from starch. All chemicals used were of analytical grade.

\section{Dough Preparation}

Four formulations of biscuits with low sucrose and lipid contents were prepared (Table I). The formulations included biscuits prepared with wheat flour (W), wheat flour and skim milk (WM), 
wheat flour and corn starch (WC), and wheat flour, corn starch, and skim milk (WCM). According to the classification of Manley (2000d), these recipes with about 19 units of sugar and about 8 units of lipid to 100 units of flour correspond to semisweet biscuits. But the baking conditions and the final moisture content differed from traditional semisweet biscuits: instead of a baking time of 5-6 min and a final moisture content of 1-2\% (Manley 2000d), we used longer baking times, and the moisture content of biscuits was $2.8-5.9 \%$ (Table II).

Solid ingredients were mixed with $50 \mathrm{~g}$ of tap water during 90 sec at low speed $(700 \mathrm{rpm})$ in a kneading Philips Cucina mixer (Sao Paulo, Brazil). Dough was then put into a polyethylene bag, and $10 \mathrm{~g}$ of corn oil was added. The dough was manually mixed in the bag and left for $10 \mathrm{~min}$ at room temperature. The dough was then laminated ten times in a Pastafácil roller laminator (Buenos Aires, Argentina), reaching a thickness of $0.6 \mathrm{~cm}$, and left at room temperature for $15 \mathrm{~min}$ in a polypropylene bag. After this time, the sheet of dough was punctured. Rectangles of dough $(2.5 \times 5 \mathrm{~cm})$ were placed on a silicon film and baked in an oven (F9M, Ariston, Fabriano, Italy) at 120 or $170^{\circ} \mathrm{C}$ with forced convection for different lengths of time (Table III) to achieve a final moisture content lower than $6 \%$ and a water activity lower than 0.5 . The temperatures of the oven and the dough rectangles during baking were registered by means of thermocouples. Table III shows the baking time and the temperatures of the oven and center of the dough for each formulation and baking condition. As expected, the baking time at $170^{\circ} \mathrm{C}$ was lower than the baking time at $120^{\circ} \mathrm{C}$.

\section{Moisture Content of Biscuits}

The moisture content was estimated through weight loss after heating the sample in an oven at $105^{\circ} \mathrm{C}$ (AOAC 1984).

\section{Water Activity of Biscuits}

The water activity of biscuits was determined at $25^{\circ} \mathrm{C}$ with an AquaLab Series 3 TE device (Decagon Devices, Pullman, Wash-

TABLE I

Biscuit Formulations ${ }^{\mathrm{a}}$

\begin{tabular}{lcccc}
\hline Ingredients & W & WM & WC & WCM \\
\hline Wheat flour, g (\%) & $130(60.1)$ & $130(55.0)$ & $70(32.4)$ & $70(29.6)$ \\
Skim milk powder, g (\%) & $0(0.0)$ & $20(8.5)$ & $0(0.0)$ & $20(8.5)$ \\
Corn starch, g(\%) & $0(0.0)$ & $0(0.0)$ & $60(27.7)$ & $60(25.4)$ \\
Sucrose, g (\%) & $25(11.6)$ & $25(10.6)$ & $25(11.6)$ & $25(10.6)$ \\
Corn oil, g(\%) & $10(4.6)$ & $10(4.1)$ & $10(4.6)$ & $10(4.1)$ \\
Water, g (\%) & $50(23.1)$ & $50(21.2)$ & $50(23.1)$ & $50(21.2)$ \\
Baking powder, g (\%) & $1.3(0.6)$ & $1.3(0.6)$ & $1.3(0.6)$ & $1.3(0.6)$ \\
\hline
\end{tabular}

a $\mathrm{W}=$ biscuits prepared with wheat flour; $\mathrm{WM}=$ biscuits prepared with wheat flour and skim milk; WC = biscuits prepared with wheat flour and corn starch; and WCM = biscuits prepared with wheat flour, corn starch, and skim milk. All ingredients are expressed in grams $(\mathrm{g})$ and in percentages of wet weight $(\%)$. ington). Following this technique, the sample was placed in a sample cup. When the water activity of the sample and the relative humidity of the air were in equilibrium, the measurement of the headspace humidity gave the water activity of the sample.

\section{Texture of Biscuits}

The width and thickness of biscuits were measured with a vernier caliper, and their fracture properties were studied by a threepoint bending test performed $24 \mathrm{hr}$ after baking. This test was carried out at room temperature with a TA.XT2i texture analyzer (Stable Micro Systems, Godalming, U.K.). Span length was 1.8 $\mathrm{cm}$, and compression speed was set at $0.1 \mathrm{~mm} / \mathrm{sec}$. The biscuits were placed on supports with the top surface down. Two series of each type of biscuit (four or five pieces each) were analyzed, and the fracture stress $(\sigma)$ was calculated as follows:

$$
\sigma=\frac{3 F L}{2 d b^{2}}
$$

where $F$ is the force $(\mathrm{N}), L$ is the distance between supports (m), $d$ is the width of the test piece $(\mathrm{m})$, and $b$ is the thickness of the test piece (m) (Baltsavias et al 1997).

\section{Differential Scanning Calorimetry}

A differential scanning calorimeter (DSC Q100, Thermal Analysis Instruments, New Castle, DE) calibrated with indium was used. Samples of 4.1-7.8 mg of freeze-dried dough and different parts of biscuits (obtained by scraping different parts of biscuits with a cutter, taking into account the color differences between bottom, center, and surface) were placed into aluminum DSC hermetic pans, and distilled water was added to achieve a starchto-water ratio of about 1:3. An empty pan was used as reference.

TABLE III

Baking Time and Temperature for Each Formulation and Baking Condition, and Time at Which the Center of the Biscuits Remained at the Highest Temperature Range ${ }^{a}$

\begin{tabular}{lcccc}
\hline & & & \multicolumn{2}{c}{ Dough Center } \\
\cline { 4 - 5 } Formulation & $\begin{array}{c}\text { Baking } \\
\text { Time (min) }\end{array}$ & $\begin{array}{c}\text { Baking } \\
\text { Temp. }\left({ }^{\circ} \mathbf{C}\right)\end{array}$ & $\begin{array}{c}\text { Temp. } \\
\text { Range }\left({ }^{\circ} \mathbf{C}\right)\end{array}$ & $\begin{array}{c}\text { Time at Temp. } \\
\text { Range }(\mathbf{m i n})\end{array}$ \\
\hline W & 100 & 120 & $101-110$ & 87 \\
& 20 & 170 & $135-150$ & 13 \\
WM & 90 & 120 & $108-118$ & 74 \\
& 18 & 170 & $150-160$ & 13 \\
WC & 80 & 120 & $110-120$ & 65 \\
& 15 & 170 & $140-170$ & 11 \\
WCM & 80 & 120 & $110-120$ & 65 \\
& 15 & 170 & $110-170$ & 13 \\
\hline
\end{tabular}

${ }^{a} \mathrm{~W}=$ biscuits prepared with wheat flour; $\mathrm{WM}=$ biscuits prepared with wheat flour and skim milk; $\mathrm{WC}=$ biscuits prepared with wheat flour and corn starch; and WCM = biscuits prepared with wheat flour, corn starch, and skim milk.

TABLE II

Moisture Content, Water Activity, Thickness, Force, and Fracture Stress of Biscuits ${ }^{\text {a }}$

\begin{tabular}{lcccccc}
\hline Formulation & Baking Temp. $\left({ }^{\circ} \mathbf{C}\right)$ & Moisture Content $(\boldsymbol{\%})$ & Water Activity & Thickness $(\mathbf{c m})$ & Force $(\mathbf{N})$ & Fracture Stress $\left(\mathbf{k N} / \mathbf{m}^{\mathbf{2}}\right)$ \\
\hline $\mathrm{W}$ & 120 & $4.9 \mathrm{c}$ & $0.41 \mathrm{~b}$ & $0.67 \mathrm{c}$ & $89.8 \mathrm{c}$ & $2,137.8 \mathrm{c}$ \\
& 170 & $5.9 \mathrm{~d}$ & $0.31 \mathrm{ab}$ & $0.63 \mathrm{bc}$ & $14.3 \mathrm{a}$ & $379.6 \mathrm{a}$ \\
$\mathrm{WM}$ & 120 & $4.0 \mathrm{~b}$ & $0.30 \mathrm{ab}$ & $0.53 \mathrm{a}$ & $86.4 \mathrm{c}$ & $3,348.0 \mathrm{~d}$ \\
& 170 & $5.1 \mathrm{~cd}$ & $0.28 \mathrm{ab}$ & $0.58 \mathrm{ab}$ & $20.6 \mathrm{a}$ & $665.2 \mathrm{ab}$ \\
$\mathrm{WC}$ & 120 & $3.4 \mathrm{ab}$ & $0.21 \mathrm{a}$ & $0.55 \mathrm{a}$ & $30.4 \mathrm{a}$ & $1,265.1 \mathrm{~b}$ \\
$\mathrm{WCM}$ & 170 & $2.8 \mathrm{a}$ & $0.23 \mathrm{a}$ & $0.57 \mathrm{ab}$ & $15.4 \mathrm{a}$ & $470.7 \mathrm{a}$ \\
& 120 & $5.4 \mathrm{~cd}$ & $0.37 \mathrm{ab}$ & $0.59 \mathrm{ab}$ & $55.3 \mathrm{~b}$ & $2,068.1 \mathrm{c}$ \\
& 170 & $5.4 \mathrm{~cd}$ & $0.40 \mathrm{~b}$ & $0.55 \mathrm{a}$ & $22.4 \mathrm{a}$ & $934.9 \mathrm{ab}$ \\
\hline
\end{tabular}

${ }^{a} \mathrm{~W}=$ biscuits prepared with wheat flour; $\mathrm{WM}=$ biscuits prepared with wheat flour and skim milk; $\mathrm{WC}=$ biscuits prepared with wheat flour and corn starch; and $\mathrm{WCM}=$ biscuits prepared with wheat flour, corn starch, and skim milk. Values followed by the same letter are not significantly different $(\alpha<0.05)$. 
Sample and reference were heated between 20 and $120^{\circ} \mathrm{C}$ at a heating rate of $10^{\circ} \mathrm{C} / \mathrm{min}$. The peak temperature $\left(T_{\mathrm{p}}\right)$ and the enthalpy of gelatinization $(\Delta H)$ were computed from the endothermic peaks. The degree of gelatinization during baking was estimated as $100 \times\left(\Delta H_{\text {dough }}-\Delta H_{\text {biscuit }}\right) / \Delta H_{\text {dough }}$, where $\Delta H_{\text {dough }}$ is the enthalpy of gelatinization of all the starch of each dough and $\Delta H_{\text {biscuit }}$ is the enthalpy of gelatinization of the starch that did not gelatinize during baking. Determinations were performed at least in duplicate. Enthalpies were calculated on a dry basis and expressed as joules per gram of starch.

\section{X-ray Diffraction}

X-ray diffractograms of wheat flour or wheat flour-corn starch mixture, freeze-dried dough, and whole biscuits milled in a mortar to pass through a $0.5 \mathrm{~mm}$ sieve (W, WM, WC, and WCM, baked at 120 or $170^{\circ} \mathrm{C}$ ) were obtained with an X'Pert PANalytical diffractometer (Almelo, The Netherlands) operating at $40 \mathrm{kV}$ and $40 \mathrm{~mA}$ with copper radiation. The samples were scanned through a $2 \theta$ (diffraction angle) range of $2-60^{\circ}$ at $0.02^{\circ} / \mathrm{sec}$.

\section{In Vitro Starch Digestibility}

In vitro digestibility of starch was determined in whole biscuits. White bread crumbs were used as the reference (van der Merwe et al 2001). Samples of biscuits were milled in a mortar to pass through a $0.5 \mathrm{~mm}$ sieve. The digestibility was determined with pancreatic $\alpha$-amylase type VI-B from porcine pancreas, according to the method described by Singh et al (1982) with some modifications (Conforti and Lupano 2008): about $30 \mathrm{mg}$ of milled biscuits was weighed in four glass tubes, three for the reaction and one for the blank. The samples were dispersed in $5 \mathrm{~mL}$ of $0.2 \mathrm{M}$ phosphate buffer, $\mathrm{pH} 6.9$, and $0.5 \mathrm{~mL}$ of pancreatic $\alpha$-amylase $(5.9 \mathrm{mg} / \mathrm{mL}, 57.8 \mathrm{IU})$ was added only to the three reaction tubes. The suspension was incubated at $37^{\circ} \mathrm{C}$ and was mixed for $10 \mathrm{sec}$ with vortex every $30 \mathrm{~min}$ for $120 \mathrm{~min}$. After this time, tubes were placed in a boiling water bath for 5 min to inactivate the enzyme completely. Aliquots of $0.15 \mathrm{~mL}$ were removed from each tube, and the released maltooligosaccharides were determined with 3,5dinitrosalicylic acid. Maltose was used as a standard. Results were expressed as percent of maltose per milligram of dry sample with respect to the same measure for dry white bread. Determinations were performed twice in triplicate.

TABLE IV

Peak Temperature $\left(T_{\mathrm{p}}\right)$ and Enthalpy of Gelatinization $(\Delta H)$ of Wheat Starch Corresponding to Dough and Biscuits Prepared Without or With Skim Milk and Baked at 120 or $170^{\circ} \mathrm{C}^{\mathrm{a}}$

\begin{tabular}{lcllll}
\hline Formulation & $\begin{array}{c}\text { Temp. } \\
\left({ }^{\circ} \mathbf{C}\right)\end{array}$ & $\begin{array}{c}\text { Dough or } \\
\text { Part } \\
\text { of Biscuit }\end{array}$ & $\boldsymbol{T}_{\mathbf{p}}\left({ }^{\circ} \mathbf{C}\right)$ & $\begin{array}{c}\Delta \boldsymbol{H} \\
(\mathbf{J} / \mathbf{g} \text { of } \\
\mathbf{s t a r c h})^{\mathbf{b}}\end{array}$ & $\boldsymbol{G}(\boldsymbol{\%})$ \\
\hline $\mathrm{W}$ & $\ldots$ & Dough & 66.2 & 8.5 & $\ldots$ \\
& 120 & Surface & $66.5 \mathrm{a}$ & $6.3 \mathrm{bc}$ & $26 \mathrm{ab}$ \\
& & Center & $77.9 \mathrm{c}$ & $1.3 \mathrm{a}$ & $85 \mathrm{c}$ \\
& & Base & $70.2 \mathrm{ab}$ & $6.3 \mathrm{bc}$ & $26 \mathrm{ab}$ \\
& \multirow{2}{*}{170} & Surface & $70.9 \mathrm{~b}$ & $4.8 \mathrm{~b}$ & $44 \mathrm{~b}$ \\
& & Center & $77.8 \mathrm{c}$ & $0.4 \mathrm{a}$ & $95 \mathrm{c}$ \\
$\mathrm{WM}$ & $\ldots$ & Base & $72.3 \mathrm{~b}$ & $2.9 \mathrm{ab}$ & $66 \mathrm{bc}$ \\
& $\ldots$ & Dough & 67.3 & 9.2 & $\ldots$ \\
& 120 & Surface & $68.2 \mathrm{a}$ & $8.3 \mathrm{c}$ & $10 \mathrm{a}$ \\
& & Center & $73.3 \mathrm{~b}$ & $6.7 \mathrm{bc}$ & $27 \mathrm{ab}$ \\
& \multirow{2}{*}{170} & Base & $69.0 \mathrm{ab}$ & $7.3 \mathrm{bc}$ & $21 \mathrm{ab}$ \\
& Surface & $68.3 \mathrm{a}$ & $6.3 \mathrm{bc}$ & $32 \mathrm{ab}$ \\
& & Center & $74.2 \mathrm{bc}$ & $0.7 \mathrm{a}$ & $82 \mathrm{c}$ \\
& & Base & $72.8 \mathrm{~b}$ & $2.8 \mathrm{ab}$ & $70 \mathrm{bc}$ \\
\hline
\end{tabular}

a Distilled water was added to achieve a starch-to-water ratio of 1:3 in the differential scanning calorimetry assays. $\mathrm{W}=$ biscuits prepared with wheat flour; $\mathrm{WM}=$ biscuits prepared with wheat flour and skim milk; and $G=$ degree of gelatinization during baking, estimated as $100 \times\left(\Delta H_{\text {dough }}-\Delta H_{\text {biscuit }}\right) / \Delta H_{\text {dough }}$. Values followed by the same letter are not significantly different $(\alpha<0.05)$.

b Dry basis.

\section{Statistics}

An analysis of variance of the data was performed using Systat statistical software (Chicago, IL). A least significant difference test with a confidence interval of $95 \%$ was used to compare the means.

\section{RESULTS AND DISCUSSION}

\section{Baking}

Table III shows the time of baking and the temperature of the center of the biscuit during baking for the different formulations. As expected, the temperature of the center of the biscuit was lower than the oven temperature, showing a temperature gradient between the surface and the center of the sample. During biscuit baking, there was a removal of water by thermal means, which involved a transfer of heat and mass (Van Arsdel 1963). The presence of corn starch increased the maximum temperature of the center of the baking biscuit and decreased the baking time. This can be explained by taking into account that gluten proteins absorb two units of water per unit of protein, whereas starch absorbs only 0.33 units of water per unit of starch (Manley 2000e). Thus, the dough in which part of the wheat flour was replaced by corn starch could lose water more rapidly and reached higher temperatures than dough prepared only with wheat flour.

\section{Fracture Stress of Biscuits}

The fracture stress of biscuits depended on the amount of wheat flour and milk and on the temperature of the oven during baking $(P<0.05)$. The biscuits with a low level of wheat flour had $46 \%$ corn starch, which could interfere with the gluten structure, producing more crumbly biscuits with lower fracture stress. The presence of milk or corn starch resulted in thinner biscuits. The force to break the biscuits in most cases did not change with the presence of milk (Table II), but because biscuits containing milk were thinner, the fracture stress was higher in these biscuits. On the other hand, when part of the wheat flour was replaced by corn starch, both the force and the fracture stress decreased in biscuits baked at $120^{\circ} \mathrm{C}$. The temperature of the oven during baking presented the main effect on the fracture stress. Biscuits baked at $120^{\circ} \mathrm{C}$ were harder than biscuits baked at $170^{\circ} \mathrm{C}$, but this effect could be counteracted by the addition of corn starch (Table II).

\section{DSC}

DSC measurements were performed to evaluate the degree of starch gelatinization during baking. The thermograms of biscuits and freeze-dried dough prepared with wheat flour (W and WM) in excess water showed a single endotherm, corresponding to the gelatinization of the starch (data not shown). $T_{\mathrm{p}}$ for the gelatinization of wheat starch for freeze-dried dough was $66.2^{\circ} \mathrm{C}$ when prepared without skim milk and $67.3^{\circ} \mathrm{C}$ when prepared with it (Table IV). The gelatinization temperature of wheat starch in excess water has been reported as $58.0^{\circ} \mathrm{C}$ for isolated starch (Tester and Morrison 1990), $61.7^{\circ} \mathrm{C}$ for wheat flour (Zamponi et al 1990), and $65.2-67.3^{\circ} \mathrm{C}$ for semisweet biscuits (Mamat et al 2010). Many food components that limit water availability, such as sucrose, shift the endotherm to higher temperatures (Lupano and González 1999; Chevallier et al 2000; Mamat et al 2010), which would explain the higher gelatinization temperature observed in Table IV. The addition of skim milk did not show a definite behavior.

The thermograms of freeze-dried dough with excess water, in which part of the wheat flour was replaced by corn starch (WC and WCM), showed two peaks (data not shown): the first one $\left(T_{\mathrm{p} 1}\right)$ at $66.4^{\circ} \mathrm{C}$ was attributed to the gelatinization of wheat starch, and the second one $\left(T_{\mathrm{p} 2}\right)$ at $75.7^{\circ} \mathrm{C}$ was attributed to the gelatinization of corn starch (Table V). The dough containing skim milk presented peak temperatures of 65.6 and $75.4^{\circ} \mathrm{C}$ for $T_{\mathrm{p} 1}$ and $T_{\mathrm{p} 2}$, respectively. $T_{\mathrm{p} 2}$ was about $6^{\circ} \mathrm{C}$ higher than the value 
reported in the literature (about $71^{\circ} \mathrm{C}$ ) (Tester and Morrison 1990; Liu et al 2006; Chung et al 2009). As in the case of samples without corn starch, this difference could be attributed to the presence of sucrose.

The values estimated from the endotherms of gelatinization corresponding to the starch that did not gelatinize during baking are shown in Tables IV and V. Pareyt et al (2009) found that sucrose, together with low moisture levels, raises the starch gelatinization temperature to such an extent that little if any of it gelatinizes during baking, and starch does not gelatinize during baking of cookie dough with $21.9 \%$ sucrose and $15.0 \%$ moisture. The recipes used in the present work presented lower sucrose content ( $12 \%$ or less) and higher moisture content (21\% or more). Under these conditions, part of the starch gelatinized during baking. When rectangles of dough were heated in the oven, the surface experienced dehydration and reached the oven temperature after a certain time. The base of the rectangles also reached the oven temperature, but it was expected that dehydration was lower in the base when compared with the surface, because the forced convection facilitated the water evaporation on the surface, whereas the silicon film and baking plate formed a barrier to the water evaporation at the base. The center of the rectangles remained at the oven temperature for a shorter period of time than the base and the surface of the biscuit, but with a higher moisture content. The results for the degree of gelatinization during baking $(G)$ shown in Tables IV and V indicated that the surface and the base of the dough had low moisture contents, which did not allow a complete gelatinization of the starch, even when they reached the gelatinization temperature; as expected, the degree of gelatinization of the starch during baking was higher in the base when compared with the surface. The highest degree of gelatinization during baking took place in the center of the biscuit. This fact can be explained by taking into account that the center of the biscuits remained at higher moisture content for a longer time. However, these conditions were not enough to gelatinize the starch completely. Significant differences $(P<0.05)$ were found in the enthalpy of gelatinization of starch $\left(\Delta H\right.$ and $\left.\Delta H_{\mathrm{T}}\right), T_{\mathrm{p}}, T_{\mathrm{p} 2}$, and $G$ when comparing different parts of the biscuits. A shift in the gelatinization temperature of the starch that remained ungelatinized after baking was observed, mainly at the center of the biscuits. The gelatinization temperature in most cases was lower at the surface, intermediate at the base, and higher in the center of the biscuit (Tables IV and V). This increase can be explained by the heat-moisture treatment that occurs during biscuit baking. The gelatinization temperature is related to the degree of perfection of the crystalline zones within the starch granules. When starch granules suffer a heat treatment below the gelatinization temperature with moisture contents below $35 \%$ water $(w / w)$, the gelatinization temperature increases (Jacobs and Delcour 1998; Laguna et al 2011).

The effect of baking temperature on starch gelatinization can be observed in Tables IV and V. The comparison of the enthalpies per gram of dried starch reflected a decrease in the values of the biscuits with respect to the corresponding dough. The decrease in the $\Delta H$ values, which reflects the degree of starch gelatinization during baking, was markedly higher in the dough baked at $170^{\circ} \mathrm{C}$ compared with dough baked at $120^{\circ} \mathrm{C}$. This is probably because the dough heated at $120^{\circ} \mathrm{C}$ could suffer considerable dehydration before reaching the gelatinization temperature. Significant differences $(P<0.05)$ were found in $\Delta H, \Delta H_{2}, \Delta H_{\mathrm{T}}, T_{\mathrm{p}}$, $T_{\mathrm{p} 2}$, and $G$ when comparing different baking temperatures (Tables IV and V). The structure of the biscuits baked at the higher temperature was fixed more rapidly, and the moisture was retained longer inside them, allowing a greater degree of starch gelatinization, which could contribute to the difference observed in the fracture stress. $T_{\mathrm{p}}$ and $\Delta H$ of wheat starch $\left(T_{\mathrm{p} 1}\right.$ and $\left.\Delta H_{1}\right)$ in samples of different parts of biscuits prepared with wheat flour and corn starch presented lower values than the corresponding dough, and in some cases both parameters were not detected (Table V). It is possible that the decrease of the first peak resulted not only from gelatinization of the wheat starch during baking but also from the shift of this peak to higher temperatures, as was observed in samples without corn starch (Table IV). When the first peak shifted to higher temperatures, it was superposed on the second peak, producing an increase of $\Delta H_{2}$, as was observed in some cases (Table V).

\section{X-ray Diffractometry}

To corroborate the results obtained by DSC, X-ray diffractometry of whole samples was performed. Patterns I and II (Figs. 1 and 2) show the X-ray diffraction of wheat flour and dough, respectively. The patterns were compatible with the A type, which is characteristic of cereal starches (Vasanthan and Bhatty 1996), with a doublet at 17 and $18^{\circ}$ and strong peaks at 15 and $23^{\circ}$. A minor peak at $20^{\circ}$ was also observed, which can be because of a small amount of V-type structure. This V-type structure was attributed to the formation of a complex between fatty acids and amylose (Zobel 1964; Shamai et al 2003).

Patterns III and IV (Figs. 1 and 2) correspond to whole biscuits baked at 120 and $170^{\circ} \mathrm{C}$, respectively. A decrease, even a lack, in

TABLE V

Peak Temperature and Enthalpy of Gelatinization of Wheat Starch $\left(T_{\mathrm{p} 1}\right.$ and $\left.\Delta H_{1}\right)$ and Corn Starch $\left(T_{\mathrm{p} 2}\right.$ and $\left.\Delta H_{2}\right)$ and Total Enthalpy of Gelatinization $\left(\Delta H_{\mathrm{T}}\right)$ Corresponding to Dough and Biscuits Prepared with Wheat Flour and Corn Starch Without or With Skim Milk ${ }^{\mathrm{a}}$

\begin{tabular}{|c|c|c|c|c|c|c|c|c|}
\hline Formulation & $\begin{array}{c}\text { Temperature } \\
\left({ }^{\circ} \mathbf{C}\right)\end{array}$ & $\begin{array}{c}\text { Dough or Part } \\
\text { of Biscuit }\end{array}$ & $T_{\mathrm{p} 1}\left({ }^{\circ} \mathrm{C}\right)$ & $T_{\mathrm{p} 2}\left({ }^{\circ} \mathrm{C}\right)$ & $\begin{array}{c}\Delta H_{1} \\
(\mathrm{~J} / \mathrm{g} \text { of } \mathrm{starch})^{\mathrm{b}}\end{array}$ & $\begin{array}{c}\Delta H_{2} \\
(\mathrm{~J} / \mathrm{g} \text { of } \operatorname{starch})^{\mathrm{b}}\end{array}$ & $\begin{array}{c}\Delta H_{\mathrm{T}} \\
(\mathrm{J} / \mathrm{g} \text { of } \operatorname{starch})^{\mathrm{b}}\end{array}$ & $G(\%)$ \\
\hline \multirow[t]{7}{*}{ WC } & & Dough & 66.4 & 75.7 & 5.7 & 8.3 & 7.1 & $\ldots$ \\
\hline & 120 & Surface & $64.9 \mathrm{a}$ & $75.0 \mathrm{a}$ & $1.5 \mathrm{a}$ & $9.4 \mathrm{c}$ & $5.8 \mathrm{bc}$ & $18 \mathrm{~b}$ \\
\hline & & Center & $67.2 \mathrm{a}$ & $78.5 c$ & $0.3 \mathrm{a}$ & $9.7 \mathrm{c}$ & $5.5 b c$ & $23 b$ \\
\hline & & Base & $65.6 \mathrm{a}$ & $75.2 \mathrm{a}$ & $2.4 \mathrm{ab}$ & $10.7 \mathrm{c}$ & $7.0 \mathrm{c}$ & $2 a$ \\
\hline & 170 & Surface & $65.5 \mathrm{a}$ & $74.7 \mathrm{a}$ & $2.3 \mathrm{ab}$ & $9.3 \mathrm{c}$ & $6.2 b c$ & $13 a b$ \\
\hline & & Center & nd & $81.6 \mathrm{~d}$ & nd & $4.8 \mathrm{a}$ & $2.6 \mathrm{a}$ & $63 d$ \\
\hline & & Base & $66.9 \mathrm{a}$ & $77.0 \mathrm{~b}$ & $0.9 \mathrm{a}$ & $7.6 b$ & $4.6 b$ & $35 b$ \\
\hline \multirow[t]{7}{*}{ WCM } & $\ldots$ & Dough & 65.6 & 75.4 & 6.9 & 11.0 & 9.2 & $\ldots$ \\
\hline & 120 & Surface & $66.3 \mathrm{a}$ & $75.2 \mathrm{a}$ & $3.7 b$ & $10.2 \mathrm{c}$ & $7.3 c$ & $21 b$ \\
\hline & & Center & $65.4 \mathrm{a}$ & $79.2 \mathrm{c}$ & $0.3 \mathrm{a}$ & $8.0 \mathrm{bc}$ & $4.6 b$ & $50 \mathrm{~cd}$ \\
\hline & & Base & nd & $75.3 \mathrm{a}$ & nd & $11.4 \mathrm{c}$ & $6.3 b c$ & $32 b$ \\
\hline & 170 & Surface & $66.5 \mathrm{a}$ & $75.8 \mathrm{a}$ & $2.2 \mathrm{ab}$ & $7.6 \mathrm{~b}$ & $5.2 b$ & $43 c$ \\
\hline & & Center & nd & $80.5 d$ & nd & $5.0 \mathrm{a}$ & $2.8 \mathrm{a}$ & $70 \mathrm{~d}$ \\
\hline & & Base & nd & $77.4 \mathrm{~b}$ & nd & $6.4 \mathrm{a}$ & $3.5 \mathrm{ab}$ & $62 d$ \\
\hline
\end{tabular}

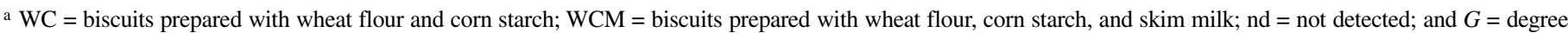

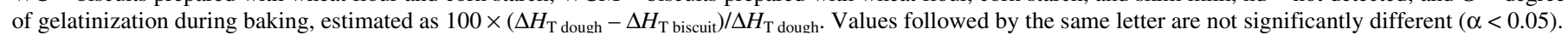
b Dry basis. 
the peak intensity can be observed, mainly in peaks at 15 and $23^{\circ}$, indicating a decrease in the relative crystallinity, with an increase in the amorphous region. These results are in agreement with those found by Mamat et al (2010) in commercial semisweet biscuits. At the same time, the peak at $20^{\circ}$ increased, which may be attributed to the formation of a complex between lipids and amylose during baking. At least $90 \%$ of the lipids from wheat starch are lysophospholipids, which may occur as inclusion complexes inside the helical segments of amylose (Jovanovich et al 1992). Zobel et al (1988) found that when corn starch was heated, even at low moisture content $\left(1 \mathrm{hr}\right.$ at $175^{\circ} \mathrm{C}$ with 10 or $16 \%$ moisture), a V-type structure began to appear prior to gelatinization, with retention of A structure.

Gelatinization causes starch granules to lose their crystallinity. The peak intensities of the semisweet biscuits showed that starch granules were not completely gelatinized, that is, they retained some crystallinity. These effects were more important in dough baked at $120^{\circ} \mathrm{C}$, in accordance with DSC results.

\section{Starch Digestibility and Stress Fracture of Biscuits}

The temperature of the oven had the major effect on starch digestibility (Fig. 3). Clearly, biscuits baked at higher temperature presented higher starch digestibility, which correlated with the results of DSC and X-ray diffractometry discussed earlier. At the low oven temperature, the dough could suffer considerable dehydration before reaching the gelatinization temperature and, thus, only a small percentage of starch gelatinized. As a consequence, starch was less available for enzymatic attack. The presence of milk and the amount of wheat flour were not significant $(P>0.05)$ on the starch digestibility, that is, biscuits with or without milk, prepared only with wheat flour or by replacing part of wheat flour by corn starch, presented the same starch digestibility.

\section{CONCLUSIONS}

The presence of milk resulted in thinner biscuits and, as a consequence, ones with higher fracture stress. Biscuits in which part of the wheat flour was replaced by corn starch had lower fracture stress than biscuits with only wheat flour.

Neither milk nor corn starch affected the starch digestibility of biscuits, but it was possible to modify the texture and starch di-

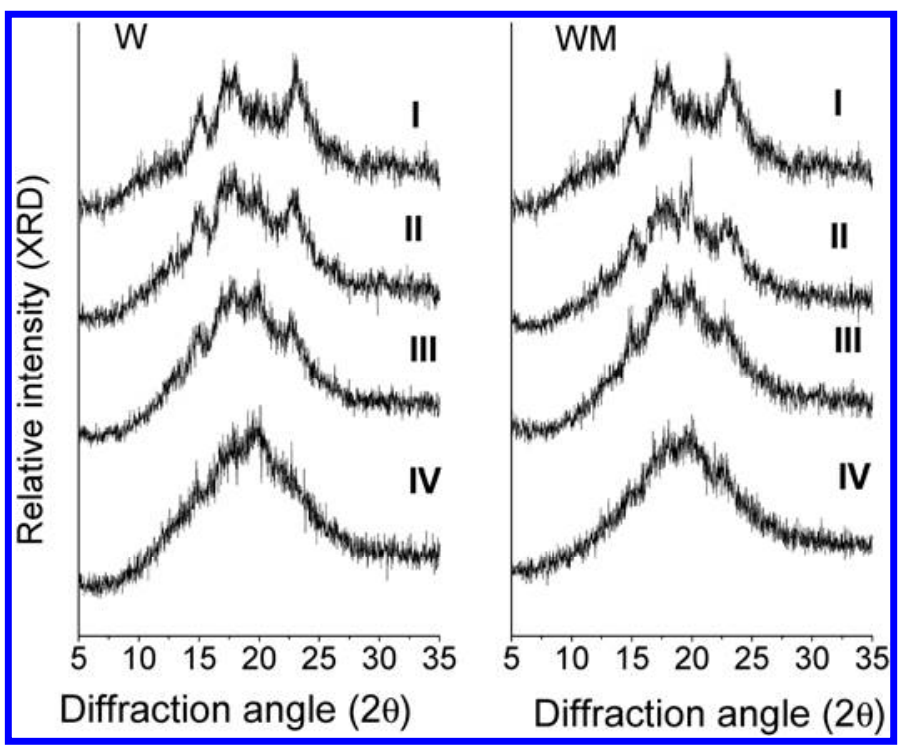

Fig. 1. X-ray diffraction patterns of flour, dough, and biscuits prepared with wheat flour without (W) or with skim milk (WM). I = flour; II = freeze-dried dough; III = biscuits baked at $120^{\circ} \mathrm{C}$; and IV = biscuits baked at $170^{\circ} \mathrm{C}$. The diffraction patterns have been offset for clarity. gestibility of biscuits with the same dough formulation by varying the baking conditions. The biscuits baked at low temperature were harder than the biscuits baked at high temperature, but this effect could be counteracted by the addition of corn starch. The degree of starch gelatinization and digestibility was higher in biscuits baked at higher temperatures. The biscuits baked at higher temperature retained more moisture inside them, allowing a greater degree of starch gelatinization, which could contribute to the differences observed in the fracture stress.

\section{ACKNOWLEDGMENTS}

This investigation was supported by a grant from the Consejo Nacional de Investigaciones Científicas y Técnicas (CONICET, PIP No. 1643). Authors are members of the researcher career of the CONICET.

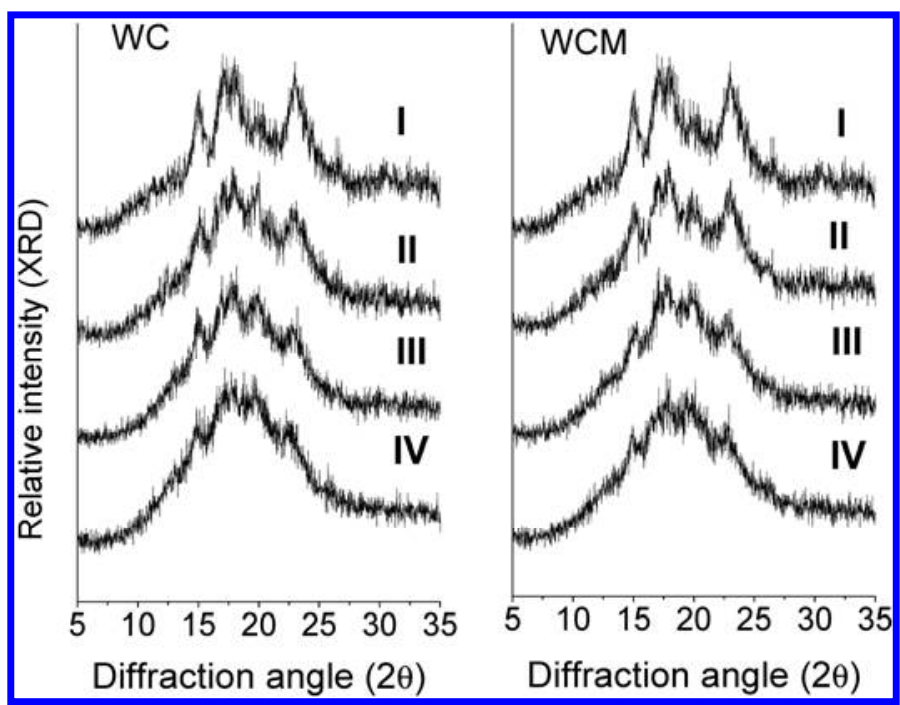

Fig. 2. X-ray diffraction patterns of flour-corn starch mixture, dough, and biscuits prepared with wheat flour and corn starch without (WC) or with skim milk (WCM). I = flour-corn starch mixture; II = freeze-dried dough; III = biscuits baked at $120^{\circ} \mathrm{C}$; and IV = biscuits baked at $170^{\circ} \mathrm{C}$. The diffraction patterns have been offset for clarity.

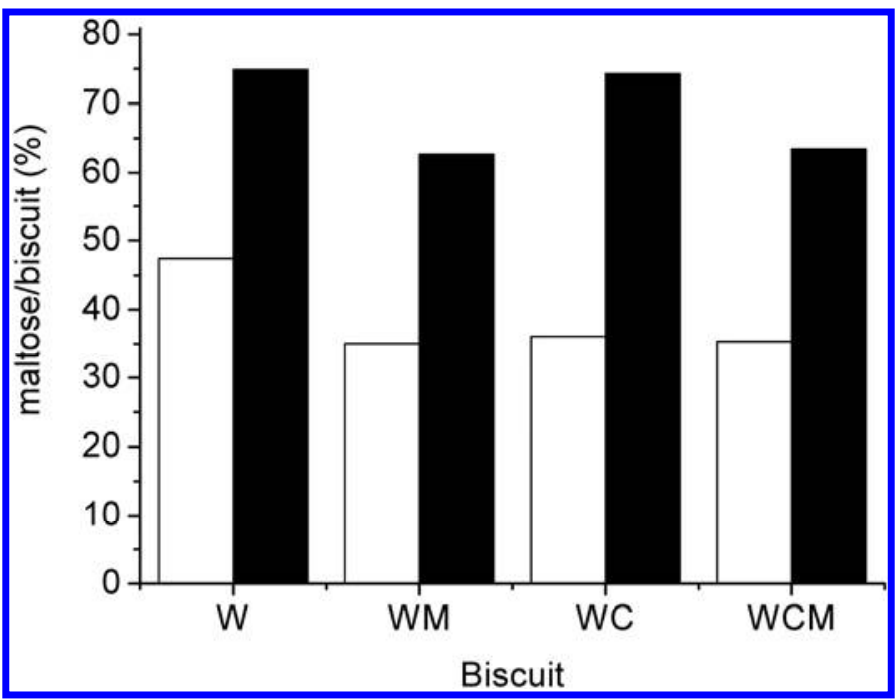

Fig. 3. In vitro starch digestibility of biscuits, expressed as $100 \times[(\mathrm{mg}$ of maltose $/ 100 \mathrm{mg}$ of dry sample)/(mg of maltose/100 $\mathrm{mg}$ of dry white bread)]. Open bars indicate biscuits baked at $120^{\circ} \mathrm{C}$; solid bars indicate biscuits baked at $170^{\circ} \mathrm{C}$. (Least significant difference at 0.05 level $=$ 10.0.) $\mathrm{W}=$ biscuits prepared with wheat flour; $\mathrm{WM}=$ biscuits prepared with wheat flour and skim milk; WC = biscuits prepared with wheat flour and corn starch; and WCM = biscuits prepared with wheat flour, corn starch, and skim milk. 


\section{LITERATURE CITED}

Aparicio-Saguilán, A., Sáyago-Ayerdi, S. G., Vargas-Torres, A., Tovar, J., Ascencio-Otero, T. E., and Bello-Pérez, L. A. 2007. Slowly digestible cookies prepared from resistant starch-rich lintnerized banana starch. J. Food Comp. Anal. 20:175-181.

AOAC. 1984. Official Methods of Analysis, 14th Ed. Association of Official Analytical Chemists: Washington, DC.

Artz, W. E., Warren, C. C., Mohring, A. E., and Villota, R. 1990. Incorporation of corn fiber into sugar snap cookies. Cereal Chem. 67:303-305.

Baltsavias, A., Jurgens, A., and van Vliet, T. 1997. Factors affecting fracture properties of short-dough biscuits. J. Texture Stud. 28:205-219.

Biliaderis, C. G., Maurice, T. J., and Vose, J. R. 1980. Starch gelatinization phenomena studied by differential scanning calorimetry. J. Food Sci. 45:1669-1674.

Chevallier, S., Colonna, P., Della Valle, G., and Lourdin, D. 2000. Contribution of major ingredients during baking of biscuit dough systems. J. Cereal Sci. 31:241-252.

Chung, H. J., Hoover, R., and Liu, Q. 2009. The impact of single and dual hydrothermal modifications on the molecular structure and physicochemical properties of normal corn starch. Int. J. Biol. Macromol. 44:203-210.

Conforti, P. A., and Lupano, C. E. 2008. Comparative study of the starch digestibility of Araucaria angustifolia and Araucaria araucana seed flour. Starch/Stärke 60:192-198.

Jacobs, H., and Delcour, J. A. 1998. Hydrothermal modifications of granular starch, with retention of the granular structure: A review. J. Agric. Food Chem. 46:2895-2905.

Jovanovich, G., Zamponi, R. A., Lupano, C. E., and Añón, M. C. 1992. Effect of water content on the formation and dissociation of the amylose-lipid complex in wheat flour. J. Agric. Food Chem. 40:1789-1793.

Laguna, L., Salvador, A., Sanz, T., and Fiszman, S. M. 2011. Performance of a resistant starch rich ingredient in the baking and eating quality of short-dough biscuits. LWT-Food Sci. Technol. 44:737-746.

Leon, A. E., Jovanovich, G., and Añón, M. C. 1998. Gelatinization profiles of triticale starch in cookies as influenced by moisture and solutes. Cereal Chem. 75:617-623.

Liu, H., Yu, L., Xie, F., and Chen, L. 2006. Gelatinization of corn starch with different amylose/amylopectin content. Carbohydr. Polym. 65:357-363.

Lupano, C. E., and González, S. 1999. Gelation of whey protein concentrate-cassava starch in acidic conditions. J. Agric. Food Chem. 47:918923.

Mamat, H., Abu Hardan, M. O., and Hill, S. E. 2010. Physicochemical properties of commercial semi-sweet biscuit. Food Chem. 121:10291038.

Manley, D. 2000a. Meals, grits, flours and starches (other than wheat). Pages 104-111 in: Technology of Biscuits, Crackers and Cookies, 3rd Ed. Woodhead Publishing Limited: Cambridge, U.K.

Manley, D. 2000b. Milk products and egg. Pages 161-168 in: Technology of Biscuits, Crackers and Cookies, 3rd Ed. Woodhead Publishing Limited: Cambridge, U.K.

Manley, D. 2000c. Position of biscuits in nutrition. Pages 307-313 in: Technology of Biscuits, Crackers and Cookies, 3rd Ed. Woodhead Pub- lishing Limited: Cambridge, U.K.

Manley, D. 2000d. Types of biscuits. Pages 221-228 in: Technology of Biscuits, Crackers and Cookies, 3rd Ed. Woodhead Publishing Limited: Cambridge, U.K.

Manley, D. 2000e. Wheat flour and vital wheat gluten. Pages 81-103 in: Technology of Biscuits, Crackers and Cookies, 3rd Ed. Woodhead Publishing Limited: Cambridge, U.K.

McCleary, B. V,. and Monaghan, D. A. 2002. Measurement of resistant starch. J. AOAC Int. 85:665-675.

Pareyt, B., Brijs, K., and Delcour, J. A. 2009. Sugar-snap cookie dough setting: The impact of sucrose on gluten functionality. J. Agric. Food Chem. 57:7814-7818.

Pareyt, B., Goovaerts, M., Broekaert, W. F., and Delcour, J. A. 2011. Arabinoxylan oligosaccharides (AXOS) as a potential sucrose replacer in sugar-snap cookies. LWT-Food Sci. Technol. 44:725-728.

-Sagum, R., and Arcot, J. 2000. Effect of domestic processing methods on the starch, non-starch polysaccharides and in vitro starch and protein digestibility of three varieties of rice with varying levels of amylose. Food Chem. 70:107-111.

-Sáyago-Ayerdi, S. G., Tovar, J., Osorio-Díaz, P., Paredes-López, O., and Bello-Pérez, L. A. 2005. In vitro starch digestibility and predicted glycemic index of corn tortilla, black beans, and tortilla-bean mixture: Effect of cold storage. J. Agric. Food Chem. 53:1281-1285.

-Shamai, K., Bianco-Peled, H., and Simoni, E. 2003. Polymorphism of resistant starch type III. Carbohydr. Polym. 54:363-369.

Singh, J., Dartois, A., and Kaur, L. 2010. Starch digestibility in food matrix: A review. Trends Food Sci. Technol. 21:168-180.

-Singh, U., Kherdekar, M. S., and Jambunathan, R. 1982. Studies on Desi and Kabuli chickpea (Cicer arietinum L.) cultivars: The levels of amylase inhibitors, levels of oligosaccharides and in vitro starch digestibility. J. Food Sci. 47:510-512.

Tester, R. F., and Morrison, W. R. 1990. Swelling and gelatinization of cereal starches. I. Effects of amylopectin, amylose, and lipids. Cereal Chem. 67:551-557.

Van Arsdel, W. B. 1963. Phenomena of heat and mass transfer. Pages 3765 in: Food Dehydration, Vol. 1: Principles. W. B. Van Arsdel and M. J. Copley, eds. Avi: Westport, CT.

$\checkmark$ van der Merwe, B., Erasmus, C., and Taylor, J. R. N. 2001. African maize porridge: A food with slow in vitro starch digestibility. Food Chem. 72:347-353.

-Vasanthan, T., and Bhatty, R. S. 1996. Physicochemical properties of small- and large-granule starches of waxy, regular, and high-amylose barleys. Cereal Chem. 73:199-207.

-Vitali, D., Vedrina Dragojević, I., and Šebečić, B. 2009. Effects of incorporation of integral raw materials and dietary fibre on the selected nutritional and functional properties of biscuits. Food Chem. 114:1462-1469.

Zamponi, R. A., Giner, S. A., Lupano, C. E., and Añón, M. C. 1990. Effect of heat on thermal and functional properties of wheat. J. Cereal Sci. 12:279-287.

Zobel, H. F. 1964. X-ray analysis of starch granules. Pages 109-113 in: Methods in Carbohydrate Chemistry. R. L. Whistler, ed. Academic Press: Orlando, FL.

Zobel, H. F., Young, S. N., and Rocca, L. A. 1988. Starch gelatinization: An X-ray diffraction study. Cereal Chem. 65:443-446.

[Received November 18, 2011. Accepted May 11, 2012.] 